Highland Wildlife, the revised and augmented edition of Richard Perry's In The High Grampians, long out of print, has new chapters on deer, dragonflies and dippers, so the net is spread wide. For seventeen years the author lived on upper Speyside in that fascinating area between the Cairngorms and Monadhliath, and his field work was both patient and thorough. In one 11-hour day he walked 30 miles (including 13 on the tops) with but two short halts only to encounter 13 pairs of ptarmigan and one of golden plover. For two years he traversed a mile-long control 'pitch' of the river west of Newtonmore to count the dippers occupying stations, noting variations both as to season and the height of water: on one occasion in early December there were no fewer than 21 , and on a notable day a month later he watched one swim for 45 seconds under a shelf of ice. But by May 3, after breeding, the stations were empty and remained so until August 15. Deer demanded even greater patience, since by letting them feed in towards him, he was once in the midst of stags at less than five paces distance. I enjoyed the account of grouse following a herd of 60 stags to take advantage of where they had pawed the thick snow clear.

DAVID JAMES

\title{
The Natural History of Shetland, by R. J. Berry and J. L. Johnston. New Naturalist 64. Collins, £8.50.
}

In the modern world habitats and species tend to be ignored until they are about to be destroyed. Despite all the care that has been taken to protect the Shetland environment from the impact of North Sea oil, there is some reason to fear that all the intensive work on the wildlife of Shetland, of which this excellent book is an epitome, is merely a prelude to the massive pollution of at least the marine part of that environment. The record of the shipping companies involved does not encourage hope that the North Sea, alone of the world's oilfields, will not prove an environmental disaster.

However, if the disaster should occur, we have here an excellent account of what we shall have lost. Shetland is of especial importance for its marine life, particularly seabirds, so it is especially sad that it is the marine environment that is threatened rather than the terrestrial. Shetland's terrestrial wildlife is mainly notable as an example of how impoverished this can be in an archipelago on the fringe of a continental land-mass with a fairly bleak climate. The book would have been worth writing to document this alone, so we should be grateful to the Editors of the New Naturalist for perceiving that it would be worthwhile, and to the authors for doing their job so well. Perhaps inevitably only the main habitats and vegetation and the mammals and birds are comprehensively covered; invertebrates and lower plants always get relegated to appendices, so that it takes an effort of the imagination to realise that they are the base of the whole pyramid of life, without which the more eye-catching flowering plants, mammals and birds could not exist. One day conservationists will catch up with this fact.

RICHARD FITTER

\section{Ecology of the English Chalk, by C.J. Smith. Academic Press, £23.80.}

This book is a comprehensive review of the English chalk in all its ecological aspects, with occasional reference to its continuation across the Channel. In ten chapters, usefully summarised in the Contents, it moves from geology and the making of the chalk landscape through climate, soils, vegetation and the associated fauna to economic uses of the chalklands and finally conservation. In four chapters devoted to vegetation, with particular emphasis on the grasslands, Dr Smith considers the plants in detail and offers a tentative classification of chalk grasslands. He describes vividly the fauna and some of the fascinating inter-relationships of plants and animals, and summarises the history and role of the rabbit. He also gives an up-to-date list of the surviving 'natural' areas.

This is the first textbook to deal in such depth and in such a comprehensive manner with one particular geological formation. Enough is given from the important papers to 
follow the original authors' theses, and many ecological principles and methods are described. An excellent list of references (29 pages), ranges from Defoe through the classical ecological works of Tansley, Watt and Elton to the latest scientific journals.

Dr Smith handles the wealth of detail with consummate ease, and his writing is refreshingly clear. He appears as a scientist of sense and an author of sensibility who is able to give an authoritative account of his subject, incidentally pointing out many gaps in our knowledge, and yet retaining the delight so many feel for this type of countryside. A useful textbook, it is also an important contribution to our overall knowledge of the English chalk.

JUDY POORE

Flowers of Greece and the Balkans, a field guide, by Oleg Polunin. OUP, $£ 40.00$.

The Balkans, here defined as Yugoslavia, Albania, Greece and the east Aegean islands, Bulgaria and European Turkey, have long been renowned for their rich flora; about half the species of flowering plants present in Europe occur there, and about a quarter of these are endemic. This floral treasurehouse is not fully described in this book. It is necessarily incomplete because of lacunae in our knowledge; furthermore, such families as the Gramineae, Cyperaceae, Polygonaceae and Chenopodiaceae, have been largely or completly omitted because they are 'difficult and unattractive', while large genera, such as Campanula, Centaurea and Dianthus, have been drastically curtailed. The author has treated about half the Balkan flora, the 3000 species most likely to be encountered, although many of them are only named; information on the latter, as well as the keys for identifying families and genera, must be sought in Polunin's earlier book -Flowers of Europe.

On the credit side, this book gives an excellent thumbnail sketch of the climate, topography, vegetation and history of the plant-cover of the area. It gives a delightful account (140 pages) of many 'plant-hunting' regions in the Balkans, with good, often spectacular, photographs of various botanical vistas. Of the 142 pages of illustrations, 80 are in colour. In an area which has endured almost 10,000 years of human influence, exacerbated during recent times by the tourist boom in some parts, conservation is clearly of tremendous importance. This is stressed in the book, with the 'danger status' of threatened species being fully indicated and the susceptibility of plant communities considered.

The book is aimed at English-speaking visitors to the Balkans who want to know something of its fascinating plant-life. This introduction they will get. Warts and all, it will make the journey of the botanically minded and conservation-conscious traveller more enjoyable and instructive than was hitherto possible.

\section{Jungles, edited by Edward Ayensu. Cape $£ 16$.}

At first sight just another ornament for the coffee table, this is in fact much more. It is a beautiful and useful book which presents the variety and fascination of the tropical rain forest in an attractive, readable and authoritative manner. The introduction describes the nature, origin, distribution and different kinds of rain forest, its climates, soils and how it functions and regenerates. This is followed by sections dealing with the structure of the forest and the place of the different groups of plants and animals in it; plant and animal partnerships (the place of ants, pollinators, lianas, orchids, the fascinating stories of figs and stranglers); man and the jungle; and, almost in the form of an appendix, a description of some of the main products of the forest (timbers, spices, resins etc. but, surprisingly, not fruits). The emphasis throughout is on the undisturbed forest, though there is a short account of economic uses and the present rapid disappearance of the forest.

The text is generally excellent, as one would expect from the authors selected to contribute. Each account is balanced and accurate and avoids the exaggeration of so 